\title{
SOCIAL NETWORKING SITES AND CONSUMER ENGAGEMENT
}

\author{
Rahul Sharma \\ Assistant Professor \\ School of Business \\ Lovely Professional University
}

\begin{abstract}
The growth of the social networking phenomenon across the Internet - led by social networking sites like Facebook, Twitter and LinkedIn etc. - has altered the playing field for business and consumer marketers of all sorts. It is practically impossible to think of a comprehensive marketing strategy in the absence of social networking as one of the key ingredients. In fact, social networking sites have already found a place in every marketers promotion mix today. Human beings have always sought to live in social environments. To a significant level, social networking sites have shifted social networking to Internetand the growth of this medium of networking has been explosive. The paper carries out an empirical research to understand the usage pattern of the social networking sites by social networkers and an effort has been made to study the value creation process for brands through social networking sites with respect to momentum effect leading to increase in advocacy and loyalty. Various Statistical Tests have been applied to support the research hypothesis.
\end{abstract}

\section{KEYWORDS}

SNS, Social Media, Consumer engagement, Online branding, Social network and momentum effect

\section{INTRODUCTION}

In a short time, the networking sites have grown from a niche online activity into a phenomenon through which tens of millions of internet users are connected, both in their leisure time, and at work.There is a common misconception that social media and social networking sites (SNS) are two synonymous terms. Social media are tools for sharing and discussing information. It can be described as a kind of online media which encourages every member for feedback and contribution. It is a social instrument of two way communication facilitating the sharing of information between users within a defined network via web 2.0 (O'Reilly, 2005). It involves online activities in which the user contributes to content creation. This media encourages user involvement which can be as simple as posting comments or giving votes or as complex as recommending content to other user on the basis of preferences of people with similar interests and lifestyle. Thus social media can be described as a broad term inclusive of activities where people create content, share it, bookmark it and network at a phenomenal rate. On the other hand social networking sites are a place where in one forms communities of interest to connect to others. Social networking sites utilize social media technology to connect with people and build relationships. Social networking sites allow individuals to construct their profile within a bounded system, share with other users and view and traverse their list of connections and those made by others within the system (Boyd \& Ellison, 2007). It can be thus concluded that social networking sites are a form of social media.The increasing dependence on technology for basic communication highlights the importance of analyzing how these networking

\author{
Dr. Rajesh Verma \\ Professor \\ School of Business \\ Lovely Professional University
}

sites are affecting daily processes. Anyone including teens and young adults, women, men, affluent consumers, and older individuals can join a social network site. Once registered the person can begin to socialize and create his/her own network of friends with common interests or goals. Sites like Facebook, Twitter, LinkedIn are influencing the way users establish, maintain and cultivate a range of social relationships, from close friendships to casual acquaintances.Consumers today want to be more informed about products before they make the purchase. Most importantly, social networks are extremely capable of informing and influencing purchase decisions, as many users now trust their peer opinions more than the marketing strategists. Customers now have the power to talk back at the brand and broadcast their opinions of the brand. Therefore, marketers have no choice but to treat them differently and with greater respect. The increasing conduciveness of people to SNS has led to fast adoption of the medium by companies. What makes these sites so appealing for companies is the ability to build a "friends" network of people who are passionate about the particular brand, and consumers can add a brand as a "friend" and use the brand's images, logos to personalize their profile. Brands are also setting up profile on these sites, accepting SNS users as "friends", to reach out to consumers. Brands like Adidas, BMW and Coco-Cola have created circles of "friends" that have become brand building hubs (McKinsey, 2007). The way SNS works, a consumer may visit the Nike's brand page and see a great wallpaper to add to his or her profile. Maybe tell a few friends about it, too. Then some other friends see it when visiting the Nike's brand page. The impact of the Nike download to user"s profile (in the form of like or something else) builds momentum as more and more people use it, choose to pass it along or are simply exposed to the nike image. Hence if on social networking site the message doesn "t stop once communicated; there is "Momentum Effect". The Momentum Effect occurs when people pass along brand-related content to a peer, or use a brand as a reference point in stories of who they are(TNS, TRU \& Marketing evolution, 2007). So if we add in Consumer to Consumer component to the social networking marketing model, the value chain becomes: $\mathrm{B} 2 \mathrm{C}+\mathrm{C} 2 \mathrm{C}=$ Value Creation. Marketers thus are frequently engaging with consumers through dedicated brand pages or tweeting, to keep them updated about their brands/ products and dedicating part of their marketing budgets for social network site marketing. Value is created in form of brand loyalty and brand advocacy. Brand loyalty can be treated as attachment that a customer has to a brand (Aaker, 1991). On the other hand Brand advocacy means engaging with the brand more often than the average consumer, providing input to the brand, paying a premium or purchasing more when on sale, and sharing the product.

\section{SCOPE OF THE STUDY}

The scope of study is confined to Social Networking Sites only. The study has been confined to state of Punjab as this area has the highest internet penetration compared to others states of India(Khanna, Aircel Enters Punjab, 2010). 


\section{OBJECTIVES OF STUDY}

This objective of this study is twofold.

a. To understand the usage pattern of the social networking sites by social networkers.

b. To study the value creation process for brands through social networking sites with respect to momentum effect leading to increase in advocacy and loyalty.

\section{RESEARCH METHODOLOGY}

The study is based on descriptive research design. In this study the data and characteristics of the population has been described in relation to the usage pattern and brand following on social networking sites. The survey was conducted online through social networking sites and responses of 150 social networkers were collected. The instrument (questionnaire) was put over google docs and the link was sent to users to fill the instrument through various social networking sites like Facebook, Orkut, Twitter, LinkedIn, Hi5, Bebo etc. The respondents and other people on different social networking sites were also requested to post the link from their profile. So the sampling technique used was non-probability convenience sampling.

Table 1.1 Respondent profile

\begin{tabular}{|l|l|l|}
\hline Variable* $^{*}$ & Classification & Total N (\%) \\
\hline Gender & Male & 67 \\
& Female & 83 \\
\hline Age & Less than 18 & 00 \\
& $18-24$ & 79 \\
& $25-39$ & 66 \\
& $40-60$ & 05 \\
\hline
\end{tabular}

*at $95 \%$ the two variables are significantly different.

\section{Analysis}

\section{Usage Pattern of social networkers}

All the people under study revealed that most the people whether male or female log on to their social network site one to three times a day.

Table1.2- Number of times people visit their social networking profiles on an average day

\begin{tabular}{|c|c|c|c|}
\hline & Variable & Classification & $\begin{array}{l}\text { Total } \quad \mathrm{N} \\
(\%)\end{array}$ \\
\hline \multirow{8}{*}{$\begin{array}{l}\text { Number of } \\
\text { times } \\
\text { people visit } \\
\text { their social } \\
\text { networking } \\
\text { profiles on } \\
\text { an average } \\
\text { day }\end{array}$} & \multirow{4}{*}{ Male } & Not even once & $0(0 \%)$ \\
\hline & & $1-3$ times & $47(70 \%)$ \\
\hline & & 4-6 times & $14(21 \%)$ \\
\hline & & 7 or more times & $6(9 \%)$ \\
\hline & \multirow{4}{*}{ Female } & Not even once & $0(0 \%)$ \\
\hline & & $1-3$ times & $52(63 \%)$ \\
\hline & & 4-6 times & $22(26 \%)$ \\
\hline & & 7 or more times & $9(11 \%)$ \\
\hline
\end{tabular}

The responses revealed that whether it is male or female, they don't like to $\log$ on to the social networking site in the early morning or before going to school or work. The preferable time for most of the people to use social network site is either evening or late night.Social networks are not just an afterschool or after-work snack. In fact, social networking users of all ages report their real and virtual worlds need to be synched throughout the day, with each making the other more vivid. Respondents agreed there's little, if any, line between their virtual and real lives.

\begin{tabular}{|c|c|c|c|}
\hline & Variable & Classification & $\begin{array}{l}\text { Total } \\
(\%)\end{array}$ \\
\hline \multirow{14}{*}{$\begin{array}{l}\text { Preferred } \\
\text { time of the } \\
\text { day for } \\
\text { using } \\
\text { Social } \\
\text { network } \\
\text { site }\end{array}$} & \multirow{2}{*}{$\begin{array}{l}\text { Early } \\
\text { Morning }\end{array}$} & Male & $5(7 \%)$ \\
\hline & & Female & $4(5 \%)$ \\
\hline & \multirow{2}{*}{$\begin{array}{l}\text { Before } \\
\text { going to } \\
\text { school/ } \\
\text { work }\end{array}$} & Male & $4(6 \%)$ \\
\hline & & Female & $4(5 \%)$ \\
\hline & \multirow{2}{*}{$\begin{array}{l}\text { During } \\
\text { Lunch }\end{array}$} & Male & $5(7 \%)$ \\
\hline & & Female & $4(5 \%)$ \\
\hline & \multirow{2}{*}{$\begin{array}{l}\text { At school/ } \\
\text { work }\end{array}$} & Male & $7(10 \%)$ \\
\hline & & Female & $7(8 \%)$ \\
\hline & \multirow{2}{*}{$\begin{array}{l}\text { After } \\
\text { school/ } \\
\text { work }\end{array}$} & Male & $16(24 \%)$ \\
\hline & & Female & $16(19 \%)$ \\
\hline & \multirow{2}{*}{ In Evening } & Male & $37(55 \%)$ \\
\hline & & Female & $57(68 \%)$ \\
\hline & \multirow{2}{*}{$\begin{array}{l}\text { Late Night } \\
\text { (10 pm to } 4 \\
\text { am) }\end{array}$} & Male & $38(56 \%)$ \\
\hline & & Female & $56(67 \%)$ \\
\hline
\end{tabular}

Table1.3- Preferred time of the day for using Social network site

Most of the people who are active over social network sites use these sites near to three hours in a day. This time spent is almost $12.5 \%$ of their hours in a day.Social networking site activity is consuming a significant time of the users making it a very attractive place for the marketers to influence prospects or existing consumers.

\begin{tabular}{|c|c|c|c|}
\hline & Variable & Classification & $\begin{array}{l}\text { Total } \quad \mathrm{N} \\
(\%)\end{array}$ \\
\hline \multirow{8}{*}{$\begin{array}{l}\text { Time spent } \\
\text { on social } \\
\text { networking } \\
\text { site in a day }\end{array}$} & \multirow{4}{*}{ Male } & Less than 1 hour & $29(43 \%)$ \\
\hline & & 1 to 3 hours & $28(42 \%)$ \\
\hline & & 4 to 6 hours & $7(10.5 \%)$ \\
\hline & & 7 hours or more & $3(4.5 \%)$ \\
\hline & \multirow{4}{*}{ Female } & Less than 1 hour & $33(40 \%)$ \\
\hline & & 1 to 3 hours & $36(43 \%)$ \\
\hline & & 4 to 6 hours & $7(8.5 \%)$ \\
\hline & & 7 hours or more & $7(8.5 \%)$ \\
\hline
\end{tabular}

Table1.4- Time spent on social networking site in a day

It is fascinating to see perceived attraction that individuals have towards social networking sites. Large number of 
respondents (Male and Female) feel they are attracted to social networking sites mainly because it allows them to check update (134/ 150), get in touch with old friends (100/ $150)$, share/ 39 view photographs (86/ 150), send messages (73/ 150) and finding information on brands (66/ 150). Percentage of male and female of the total respondents in the above activities is near to equal. It can thus be concluded that social networking sites are mainly viewed as a source of entertainment (check updates, share/ view photographs and finding information on brands being the major activities for which individuals $\log$ on) and as a communication tool (that enables to stay in touch with friends and send messages).

\begin{tabular}{|c|c|c|c|}
\hline & Variable & Classification & Total \\
\hline \multirow{10}{*}{$\begin{array}{l}\text { Activities } \\
\text { over social } \\
\text { networking } \\
\text { sites }\end{array}$} & Check Updates & Male/Female & $59 / 75$ \\
\hline & Send messages & Male/Female & $34 / 39$ \\
\hline & $\begin{array}{l}\text { Share/view } \\
\text { photographs }\end{array}$ & Male/Female & $39 / 47$ \\
\hline & $\begin{array}{l}\text { Get in touch } \\
\text { with old friends }\end{array}$ & Male/Female & $47 / 53$ \\
\hline & $\begin{array}{l}\text { Watch videos/ } \\
\text { listen to music }\end{array}$ & Male/Female & $10 / 11$ \\
\hline & $\begin{array}{l}\text { Keep in touch } \\
\text { with family } \\
\text { members }\end{array}$ & Male/Female & $26 / 32$ \\
\hline & $\begin{array}{l}\text { Participate in } \\
\text { discussions }\end{array}$ & Male/Female & $6 / 10$ \\
\hline & Play games & Male/Female & $11 / 13$ \\
\hline & $\begin{array}{l}\text { Chatting with } \\
\text { girlfriend/ } \\
\text { boyfriend }\end{array}$ & Male/Female & $9 / 9$ \\
\hline & $\begin{array}{l}\text { Information } \\
\text { about brands }\end{array}$ & Male/Female & $30 / 36$ \\
\hline
\end{tabular}

Table1.5-Activities over social networking sites

\section{Social Network and Momentum Effect}

Of the people under study, $49 \%$ of the total respondents followed 1 to 3 brands on their profiles, $21 \%$ following 10 or more brands, $19 \%$ following 4 to 6 brands and $11 \%$ following 4 to 6 brands. Hence on an average 1 to 3 brands are followed by people over social network sites. It is clear that people are affiliating themselves with brands on their social networking profiles. This clearly identifies a demand for brands in the social space. The increasing power of peer to peer recommendation and the huge number of spaces that facilitate this recommendation mean that people are becoming fans with brands on their social networking platform.

Study revealed that the most followed sector on social network sites is Media and Entertainment, with social networking sites becoming a hub to receive news through the pages of newspapers and magazines. The media brands are the ones able to broadcast the most content and are therefore leading the way. The second popular sector is Fashion/ Luxury Good brands for their ability to produce entertaining content. The social demand doesn't end with Media/ Entertainment and Fashion/ Luxury Good business sectors. People want an interaction with brands across a number of categories, even if this engagement is more superficial, like just having access to breaking news, launch of new car model, to support a cause like the one of Anna Hazare ${ }^{\text {ee }}$ s movement against corruption. Hence it can be seen in categories like Automobiles, FMCG, Sport, Travel and Support Causes, there are a small number of people (respondents) engaging with brands.

The motivational factor for people joining/ following a brand page/ brand on social networking platforms vary from person to person. The main reason fans come to join a brand page or brand following is through brand invitation/ advertising followed by a friend invitation. The search factor (personal research) plays an important role, thus it is crucial for brands to be found if consumers search for them. Brand loyalty also plays a role in motivation towards brand following on the social networking platforms. Brand loyalists are consumers who will market a certain brand and talk positively about it among their friends/ peers. This is free word-of-mouth marketing for the brands and is often very effective.

\begin{tabular}{|c|c|c|}
\hline & Variable & Total N \\
\hline \multirow{4}{*}{$\begin{array}{l}\text { Motivation to } \\
\text { follow a } \\
\text { Brand or Join } \\
\text { a Brand page }\end{array}$} & $\begin{array}{l}\text { Brand } \\
\text { invitation/ } \\
\text { Advertising }\end{array}$ & 66 \\
\hline & $\begin{array}{l}\text { Friend's } \\
\text { invitation }\end{array}$ & 50 \\
\hline & $\begin{array}{l}\text { Personal } \\
\text { research }\end{array}$ & 36 \\
\hline & $\begin{array}{l}\text { Loyalty } \\
\text { towards the } \\
\text { brand }\end{array}$ & 40 \\
\hline
\end{tabular}

Table1.5- Motivation to follow a Brand or Join a Brand page

Social networking sites are a new CRM (to receive exclusive deals and offers, exclusive content) tool where the consumer wants to feel exclusive. The attachment to brand is a key motivator to advocate the brands. Demonstrating appreciation for the brand, showing what you like, and supporting the brand's values play an active role in generating advocacy. The desire to engage with the brand either through dialog with the brand's representatives or with other consumers reaches an interesting level. Regression Analysis was performed where in Brand Loyalty - the motivation factor why individuals joined brand page or followed a brand was taken a dependent variable and the suggestions that explain why individuals follow a brand on social networking sites were taken as independent variables.

\section{Coefficients}

\begin{tabular}{|c|c|c|c|c|c|}
\hline \multirow[t]{2}{*}{ Variables } & \multicolumn{2}{|c|}{ Unstandardized Coefficients } & \multirow{2}{*}{$\begin{array}{l}\text { Standardize } \\
\text { d } \\
\text { Coefficients } \\
\text { Beta }\end{array}$} & \multirow[b]{2}{*}{$\mathrm{T}$} & \multirow[b]{2}{*}{ Sig. } \\
\hline & B & Std. Error & & & \\
\hline Specially Treated by the brand/ company & .014 & .043 & .028 & .334 & .739 \\
\hline
\end{tabular}




\begin{tabular}{|l|l|l|l|l|l|}
\hline To be the spokesperson of the company & .084 & .063 & .152 & 1.334 & .184 \\
\hline To interact with the brand & -.109 & .054 & -.218 & -2.030 & .044 \\
\hline To receive exclusive deals and offers & .032 & .052 & .059 & .609 & .543 \\
\hline To receive exclusive content related to brand & -.089 & .059 & -.160 & -1.511 & .133 \\
\hline For fun and entertaining content & -.054 & .047 & -.104 & -1.148 & .253 \\
\hline Recognize and "like" a brand after seeing a friend has & .068 & .048 & .143 & 1.416 & .159 \\
\hline A friend recommends I "like" & -.098 & .053 & -.188 & -1.842 & .068 \\
\hline
\end{tabular}

a. Dependent Variable: LOYALTY

Regression Analysis was performed where in Brand Loyalty the motivation factor why individuals joined brand page or followed a brand was taken a dependent variable and the suggestions that explain why individuals follow a brand on social networking sites were taken as independent variables. In a regression line, $y=a+b x, b$ represents the slope of the regression equation, y represents the independent variable and $\mathrm{x}$ is the dependent variable. Only two factors are showing a positive slope. It shows that the independent variable "be spokesperson of the brand "e shows 0.63 variation on the dependent variable "brand loyalty". Hence it indicates the more the companies should instigate individuals to talk about their brands/ products the more the loyalty towards the brands/ products will increase.Respondents were asked to reason for following brands on their social networking profiles. 51 of the respondents followed the brand because they regularly used the brand. 46 respondents used the brand occasionally hence they followed the brand. 17 respondents have never used the brand but intend to use in the future. 13 respondents said they followed the brand because they had a friend/ family member/ opinion leader who follows the brand. 14 respondents find the brand's advertisement interesting or the brand ambassador is their role model. While 7 respondents are passive follower engaging only in following the brand on twitter or liking brand's Facebook page but don't wished to use the brand. People share information with friends or react on the wall of the brand through like button, post comments or messages and tweet about it. Thus momentum effect occurs as people are passing along brand-related content to a peer, recommending following a brand to friend. This is free word-of-mouth marketing for the brands and is often very effective leading to brand advocacy.Respondents were asked about the number of times they purchased the brand they followed on their social networking profiles over the past few months. 52\% respondents purchased the brands they followed 1 to 3 times, $14 \%$ respondents said they purchased it 4 to 6 times and $4 \%$ respondents said they purchased it 7 or more times. This indicates that the brand following over the social networking sites is converted into brand purchase either through offline or online buying channels. One inference that can be extracted is that there have been repeat purchases of the brand which denotes consumer loyalty.

\section{FINDINGS}

Very limited gender variability occurs in case usage of social networking sites. The younger audience of the society tend to accept and adopt social networking sites more, whilst the older members of the society consider it a good place for them to be a member and maintain relations with friends/ colleagues. People are affiliating themselves with brands on their social networking as on average respondents tend to follow 1 to 3 brands on their profiles. The younger adopter and younger adult are a significant audience who follow/ contribute to maximum number of brands on their social networking profile. They are the one who not only represents the future face of social network usage but a very interesting and influential audience today. Media/ Entertainment sector followed by Fashion/ Luxury goods sector are where maximum number of brands is followed. The main way fans come to join/ follow a brand page/ brand on social networking sites is through advertising followed by a friend invitation. Brand loyalty also plays a role in motivation towards brand following on the social networking platforms. The desire to engage with the brand either through dialog with the brand's representatives or with other consumers (business to consumer + consumer to consumer communication) leads to advocacy and loyalty towards the brand. The brand following over the social networking sites is converted into brand purchase either through offline or online buying channel.

\section{CONCLUSION}

The phenomenon of social networking has touched our lives in many ways - from connecting with friends, colleagues and family, providing inputs/ feedback on products and services, participating in events, to even experiencing the joy of farming on "Farmville" while sitting in our homes and offices, following tweets of famous personalities to checking out job opportunities. With the present growth and scale of social networking, we would even be able to buy products and services through the social medium. The medium is growing very fast and holds huge potential but is still in its nascent stage in India. Therefore, the time is ripe for companies to hook and eye the medium, take advantage of on the opportunity presented and become the revolutionaries of the coming years.

\section{REFRENCES}

- Aaker. (1991). Managing Brand Equity: Capitalizing on the Value of a Brand Name. New York: The Free Press.

- Adrian Palmer, N. K.-L. (2009). An experiential, social network-based approach to direct marketing. International Journal of Direct Marketing, 162 176.

- Boyd, D. M., \& Ellison, N. B. (2007). Social Network Sites: Definition, History and Scholarship. Journal of Computer-Mediated Communication, 13(1), 210-230.

- Conroy, P., \&Narula, A. (2010). A new breed of brand advocates - Social networking redefines consumer engagement. Delloite.

- Khanna, R. M. (2010, August 6). Aircel Enters Punjab. The Tribune.

- McKinsey. (2007). How companies are marketing Online: A McKinsey Global Survey. 
- O'Reilly, T. (2005, April 6). What is web 2.0? Retrieved June 12, 2011, from www.oreilly.com: http://oreilly.com/lpt/a/6228

- $\quad$ TNS, TRU \& Marketing evolution. (2007). Never Ending Friending - A Journey into Social Networking. Fox Interactive Media, Inc.
- Vogt, C., \&Knapman, S. (2008). The Atanomy of social networks. Market leaders, 40(3), 46-51. 